Technical Advisor to the United States Civil Service Commission, presided during a similar two-day program devoted to position classification and pay administration. Richard 0 . Niehoff, Division of Personnel, Tennessee Valley Authority, led a discussion of the place of training in personnel and general management; J. Fred Ogburn, Jr., Director of Personnel, City of Richmond (Virginia), and E. B. Schultz, Chief, Labor Relations Branch, Division of Personnel, Tennessee Valley Authority, served as instructors during a discussion of the problem of employee relations. The institute culminated in a banquet at which Harry L. Case, Director of Personnel, Tennessee Valley Authority, delivered the principal address. The University of Tennessee presented appropriate certificates to those who participated in the institute.

The department of political science of Marshall College sponsored a workshop on "Revising the United Nations Charter," June 1-18, 1954. Professors Conley H. Dillon and Carl Leiden served as lecturers, with the former as director, and Professor Clyde Eagle- ton of New York University was a special consultant. The workshop was attended by graduate students and teachers.

A Workshop in Practical Politics, sponsored jointly by the Washington State Citizenship Clearing House and the State College of Washington, was held on the State College campus on April 17, 1954. The workshop provided twenty leading students from the State College of Washington and six from the University of Idaho an opportunity to hear and talk to six political leaders from both political parties in the state. Assistant Professor Daniel M. Ogden, Jr. served as the director.

The Second Annual Institute on Management in Government and Business was held in Portland, Oregon, June 29, 1954. Assistant Professor Morton Kroll of the department of political science, University of Oregon, was in charge of developing plans for the program. Some thirty-five leaders from business, the federal government, and agencies of state and local government participated in the discussion of common problems of management.

\title{
OTHER ACTIVITIES
}

A Center for Middle Eastern Studies was established in the spring of 1954 at Harvard University for the purpose of integrating and reinforcing instruction in the languages, literatures, history, economies, and culture of the region extending from the eastern Mediterranean to the frontiers of India, with particular emphasis on the modern period. The director of the center is William L. Langer, Coolidge Professor of History, who will work with the Committee on Middle Eastern Studies, an advisory body representing not only various departments of the Faculty of Arts and Sciences but also specialized graduate schools like the Law School, the Littauer Center for Public Administration, the Graduate School of Business Administration, and the School of Public Health.

The function of the new center is to train specialists for academic and non-academic work in an area which has become increasingly important in world affairs and in which the interests and responsibilities of the United States have grown steadily since the end of World War II. The center provides: a Regional Studies Program for the Middle East, comparable to the Regional Studies programs already in operation at Harvard University for the Soviet Union and for East Asia; joint programs for the Ph.D. combining one of the conventional fields, such as anthropology, economics, government, history, or Semitic languages and history, with Middle Eastern Studies; and a focal point for the planning and development of post-doctoral research in various problems of the modern Middle East.

The Johns Hopkins University School of Advanced International Studies in Washington, D. C. opened an overseas branch of the school in June, 1954. Through a cooperative arrangement with the University of Rangoon, the branch will be known as the RangoonHopkins Center for Southeast Asian Studies. Under the arrangement with the University of Rangoon, a working library suited to the needs of the center will be provided, and a member of the faculty of the School of Advanced International Studies will serve as codirector of the center. The new center will provide opportunities for students from the school in Washington to carry on field study and research under effective supervision. Dr. William T. Phillips, professor of international 
economics, is the first co-director and has a group of students from the school with him in Burma to organize the work of the center.

The School of Public Administration, University of Puerto Rico, has recently completed a translation program, sponsored by the Foreign Operations Administration, under which the following works on public administration have been translated into Spanish for use in Latin America: James D. Mooney, The Principles of Organization, rev. ed.; William E. Mosher, J. Donald Kingsley, and O. Glenn Stahl, Public Personnel Administration, 3rd ed.; and L. Urwick, The Elements of Administration.

Since May, 1953, chapters of Pi Sigma Alpha, the national political science honor society, have been installed at the following institutions: North Texas State College, University of New Hampshire, State University of Iowa, American University, Washington and Lee University, and Florida State University.

The Society for Personnel Administration recently announced the appointment of a Committee on Professional Standards composed of the following members: $O$. Glenn Stahl (chairman), U.S. Civil Service Commission; Mitchell Dreese, George Washington University; Catheryn Seckler-Hudson, the American University; Lloyd M. Short, University of Minnesota; E. Charles Woods, Bureau of the Budget; and Wilton H. Dickerson, U.S. Civil Service Commission. The purpose of the committee is to study the existing literature and to outline research needs for better definition of the nature of, and requirements for, entry and progress in the field of personnel management, both public and private.

During the past few months the National Municipal League sponsored a series of ten radio broadcasts entitled "Citizens at Work." The series dramatized over the National Broadcasting Company network citizen action for community betterment in cities competing in the All-America Cities contest, conducted annually by the League and Look magazine.

The Falk Foundation of Pittsburgh has granted $\$ 105,000$ to the Citizenship Clearing House for an intensified and expanded program to prepare college students for participation in political affairs. The grant provides for continued support to Citizenship Clearing
House activities at selected colleges and universities; a summer program of seminars and workshops, which will bring together teachers of political science, college administrators, and political leaders from the major parties; and the establishment of local affiliates, particularly in the South and Midwest.

The Social Science Research Council will offer in 1955 the several types of fellowships and grants awarded in the present year, and in addition plans to hold two institutes in mathematics for social scientists in the summer of 1955. A more detailed announcement of the following offerings is to be issued in October, and applications for most types of awards will be due soon after the first of January:

Research Training Fellowships, predoctoral and postdoctoral, for "more advanced research training than that which is provided in the usual Ph.D. program." All Ph.D. requirements except the thesis must be met before tenure of fellowship may begin, but application need not be deferred until that point has been reached.

Faculty Research Fellowships, providing halftime support for research for three-year terms. Open to college and university social science teachers, normally not over 35 years of age.

Grants-in-Aid of Research, to aid scholars of established competence in meeting direct expenses of their own research projects. Not open to candidates for degrees.

Undergraduate Research Stipends, open only to college juniors, for supervised research during the summer and the ensuing senior year. Some appointees will be granted firstyear graduate study fellowships for the next year.

Institute in Mathematics for Social Scientists, eight-week sessions to be held during the summer of 1955. Open to predoctoral and postdoctoral students and younger faculty members in social sciences who wish to improve their mathematical competence. A limited number may receive stipends.

In addition to the fellowships and grants listed above, the Council will be able during the coming year to offer certain other types of assistance for study and research:

Interuniversity Summer Research Seminars will be supported on the basis described in Social Science Research Council ITEMS, March, 1954, pp. 4-6.

Summer Research Training Institutes will be organized if groups of social scientists indicate interest in intensive technical or interdisciplinary training in fields related to their 
primary interests and experience. A description of this program was published in ITEMS, June, 1954, pp. 18-19.

Legal and Political Philosophy: The Council has assumed responsibility for continuing administration of a program of predoctoral and postdoctoral fellowships for advanced study and research in this field, which was inaugurated and administered last year by the Rockefeller Foundation.

History of American Military Policy: Grants may be made to support research on this nation's military policies and impinging factors, covering any period between 1750 and 1939 except the Civil War period. Applications for these special grants should be made before November 1. This program is described in ITEMS, June, 1954, pp. 14-15.

Inquiries should if possible be made early in the autumn, so that there will be ample time for preparation of definite applications before the closing dates. The address is: Social Science Research Council, 726 Jackson Place, N.W., Washington 6, D. C.

The American Association of University Women has announced twenty-seven fellowships to be offered to American women for advanced study or research during the academic year 1955-56. The amount of the fellowships ranges from $\$ 2,000$ to $\$ 3,500$. In general, the $\$ 2,000$ fellowships will be awarded to young women who have completed residence work for the $\mathrm{Ph} . \mathrm{D}$. degree or who have already received the degree; the $\$ 2,500-\$ 3,500$ awards will be made to the more mature scholars who need a year of uninterrupted work for writing and research. Applications and supporting materials must reach the office in Washington by December 15, 1954. For detailed information, write to the Secretary, Committee on Fellowship Awards, American Association of University Women, 1634 Eye St., N.W., Washington 6, D. C.

The Washington Semester program at the American University has been expanded by the addition of a third academic unit. Colleges and universities which have recently affiliated with the program are: Baldwin-Wallace College, Boston University, Hillsdale College, Hope College, Lewis and Clark College, Mary Baldwin College, Millikin University, Mills College, Muskingum College, Ohio Wesleyan University, Oklahoma Baptist University, Otterbein College, Pacific University, the University of the South, and Union University.
By action of the Board of Regents of the University of California, the social science building on the Los Angeles campus was named Charles Grove Haines Hall in honor of the former president of the American Political Science Association. Haines Hall, which will house most of the social science departments, became the new home of the political science department in April.

The Connecticut Society for Public Administration resumed activity on an expanded scale during the past academic year, sponsoring three one-day conferences that were widely attended by young careerists in public administration, graduate students, academic persons, and political officials. The topics were intergovernmental administrative relations, statelocal fiscal relations, and public managementunion relations. Professor Karl A. Bosworth of the University of Connecticut has served as secretary-treasurer; Professor Stephen K. Bailey of Wesleyan University, as vice-president, and the president has been William Sherman, Comptroller of the Town of Greenwich.

The Maurice and Laura Falk Foundation of Pittsburgh has granted $\$ 30,000$ to Goucher College for a three-year program designed to encourage and train college women for more active participation in politics. Brownlee Sands Corrin, assistant professor of political science, has been appointed field director for this program, to be administered by the department of political science under the chairmanship of Professor C. I. Winslow.

Frederick N. Cleaveland, associate professor of political science at the University of North Carolina, is currently directing a research project concerning the role of state governments in the conduct and support of scientific research and development. The study is being financed by the National Science Foundation and will focus upon six states: California, Connecticut, New Mexico, New York, North Carolina, and Wisconsin. In each of these states there is an intensive examination of the nature and scope of scientific research and development activities carried on or supported by state government agencies, an analysis of agency organization and procedures for planning and administering research programs, and a consideration of relevant state policies regarding scientific research. The project staff is made up of a research team in each of the six states. In addition to the project director, the senior research staff includes: Hubert 
Marshall, department of political science, Stanford University; Elroy Lehmann, department of geology, Wesleyan University (Connecticut); Allan Richards, department of government and citizenship, University of New Mexico; Dean Clark Ahlberg, L.C. Smith College of Engineering; Guthrie Birkhead, the Maxwell School, Syracuse University; and Clara Penniman, Bureau of Government, University of Wisconsin. Dr. John C. Honey of the Program Analysis Office is representing the National Science Foundation in the design and planning of the research. Intensive field work was done during the summer of 1954, and the study is scheduled to be completed by June, 1955.

During the past academic year the department of political science at Northwestern University sponsored a series of discussions on the general topic, "The Nature and Uses of Theory in the Social Sciences." Papers were presented by spokesmen for the several social science departments of the University.

The University of Virginia has entered into a contract with the Department of State for a special program for ten Japanese graduate student-trainees in government for the academic year 1954-55. The project coordinator for the Japanese students will be John Gange, Director of the Woodrow Wilson Department of Foreign Affairs of the University of Virginia.

The Yale University Press has inaugurated a series of publications entitled Yale Studies in Political Science. The Regulation of Businessmen, by Robert E. Lane, assistant professor of political science at Yale University, is the first volume in the series. The editorial committee for the series consists of Frederick M. Watkins, chairman, Robert A. Dahl, and David N. Rowe. During 1953-54, Edward McWhinney served as editor of the series.

Professors John T. Holden, Robert B. Dishman, and David C. Knapp, of the department of government, University of New Hampshire, have been serving as consultants to the New Hampshire Commission to Recommend Reorganization of the Tax Structure.

Pedro Muñoz Amato, dean of the College of Social Sciences and director of the School of Public Administration, University of Puerto Rico, delivered a series of lectures on public administration at Tegucigalpa, Honduras, sponsored by the Honduran Ministry of Finance, during the last week of July. August
1-7 he lectured at the opening of the Central American School of Public Administration, which has been established in San Jose, Costa Rica, by the Technical Assistance Administration of the United Nations. He also attended a seminar on the teaching of the social sciences in Central American universities, sponsored by UNESCO and held at San José, Costa Rica, August 15-23.

Charles S. Ascher, of Brooklyn College, took part in a round table of the International Institute of Administrative Sciences at The Hague in July and in the International Congress of Comparative Law in Paris last August.

Professor Harold F. Alderfer, Director of the Institute of Local Government and professor of political science at the Pennsylvania State University, has been named as consultant to the Commission on Intergovernmental Relations and is participating in a study being conducted in South Carolina to show the impact of federal grant-in-aid programs on the state and local governments. Professor Alderfer was awarded an honorary Doctor of Laws degree by Parsons College, Fairfield, Iowa, at the June commencement in recognition of his outstanding contribution to state and local government both in the United States and abroad.

Wilfred E. Binkley, professor of political science at Ohio Northern University, is one of the two appointees of President Eisenhower to the twelve-member National Historical Publications Commission.

The personal records and semi-official correspondence of Ralph J. Bunche will be acquired by the library of the University of California (Los Angeles). Dr. Bunche graduated from UCLA in 1927.

Maurice G. Burnside, a former member of the department of political science at Marshall College, is the Democratic candidate for Congress in the Fourth Congressional District of West Virginia.

Robert P. Benedict, professor of government at Boston University, gave three lectures last July on American-European understanding in educational and cultural matters at the International Teachers' Conference, sponsored by the Centre Quaker International at Kastl Eerde, Ommen, Holland.

George I. Blanksten, of Northwestern University, spent the summer in Brazil as a member of a team of social scientists studying the 
impact of technical assistance programs, Professor Blanksten was on leave from the University during the spring, summer, and fall of 1953 for work on the project, which is directed by Professor T. E. Schultz of the department of economics at the University of Chicago.

Lynton K. Caldwell, professor of political science at Syracuse University, recently completed an assignment for the University of Michigan as consultant in public administration to the Institute of Public Administration, University of the Philippines.

Thomas I. Cook, of the Johns Hopkins University, acted as consultant to the Commission on Intergovernmental Relations in Washington during the summer months.

Joseph Dunner, of Grinnell College, who spent the summer in Western Europe, was invited to address the Deutsche Politische Gesellschaft in Munich and the Dante Alighieri Society in Rome.

D. F. Fleming, research professor of international relations at Vanderbilt University, lectured during the past summer in the Fulbright Conference on American Studies at Cambridge University on postwar american foreign policy.

H. Duncan Hall attended as an observer the Commonwealth Parliamentary Conference and Council meetings held in August and September, 1954, in central Africa. He accompanied the members of Parliament from all parts of the Commonwealth on their tour of the territories from Kenya and Uganda to Southern Rhodesia.

Roy C. Macridis, of Northwestern University, attended the International Political Science Conference on Comparative Politics at the University of Florence in April, reading a paper on comparative politics and political science. Professor Macridis visited several European and English universities after the conference.

M. Nelson McGeary, of the department of political science, Pennsylvania State University, was elected president of the Pennsylvania Political Science and Public Administration Association. His choice for the two-year term of office was made at the annual meeting of the association held in Harrisburg in April.

Charles A. Micaud, associate professor of political science at the University of Virginia, spent the summer in France doing research on communism under a Rockefeller Foundation grant.

Hans J. Morgenthau, professor of political science at the University of Chicago, lectured at the Salzburg Seminar in Austria during the summer session.

Mark Neuweld, of Western Reserve University, has been awarded a research fellowship by the Ford Foundation to make a study of the central organization of the Communist Party of the Soviet Union. On leave from Western Reserve, he will spend most of 195455 at Harvard University.

Benjamin Rivlin, of Brooklyn College, spent the summer in France and French North Africa studying Franco-Moslem relations under a grant-in-aid of the Social Science Research Council.

Wallace S. Sayre, of Columbia University, was awarded an honorary Doctor of Laws degree in June by Marshall College.

Paul D. Stewart, associate professor of political science at Marshall College, is a candidate for the Huntington Municipal Council.

William S. Stokes, professor of political science at the University of Wisconsin, will be one of the North American participants in the Conference on Responsible Freedom in the Americas, organized by Columbia University, October 25-30, 1954.

Ronald M. Stout, associate professor of political science at Colgate University, was engaged during the summer in the collection of cases for the teaching of public administration to undergraduates. Under a research grant from Colgate University, he gathered material in Albany and New York City.

Albert I. Sturm, professor of political science at West Virginia University, was a consultant to the Task Force on Water Resources and Power, Hoover Commission, during the summer.

Egbert S. Wengert, professor of political science at the University of Oregon, has been serving as a member of a constitution committee appointed by the governor and the legislature to determine whether major constitutional revision is required in Oregon. 